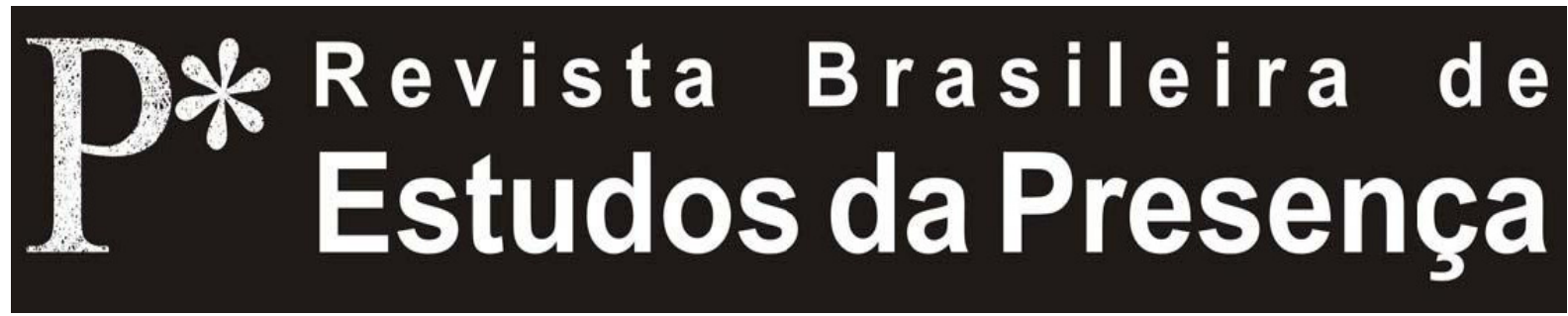

DOI - http://dx.doi.org/10.1590/2237-266033506

ISSN 2237-2660

\title{
Desejo sem Objeto
}

\author{
Mario Biagini \\ Workcenter of Jerzy Grotowski and Thomas Richards - Pontedera, Itália
}

RESUMO - Desejo sem Objeto $^{1}$ - Este texto faz uma reflexão pessoal sobre o trabalho do Workcenter of Jerzy Grotowski and Thomas Richards. Por intermédio de diferentes experiências e histórias, o artigo aborda os problemas do ofício, da artesania, da arte e da transformaçáo de si. Apresenta-se a arte como veículo e problematizam-se temáticas importantes para a área como tradição, interioridade, grupo. A partir do trabalho com os cantos tradicionais e das experiências do autor com Grotowski, o texto indaga sobre o sentido do fazer artístico.

Palavras-chave: Workcenter of Jerzy Grotowski and Thomas Richards. Performance. Teatro. Cantos Tradicionais. Grotowski.

ABSTRACT - A Desire Without an Object - This text is a personal reflection on the work of the Workcenter of Jerzy Grotowski and Thomas Richards. Through several experiences and stories, the article addresses issues of the activity, craft, art, and transformation of the self. It presents art as a vehicle and discusses issues important to the field as tradition, interiority, and group. Based on work with traditional songs and the author's experiences with Grotowski, the text questions the meaning of artistic creation.

Keywords: Workcenter of Jerzy Grotowski and Thomas Richards. Performance. Theatre. Traditional Songs. Grotowski.

RÉSUMÉ - Désir sans Objet - Ce texte propose une réflexion personnelle sur le travail du Workcenter of Jerzy Grotowski and Thomas Richards. À travers différentes expériences et histoires, cet article aborde certains problèmes inhérents au métier, à sa dimension artisanale, à l'art et à la transformation de soi. L'art est présenté ici en tant que véhicule et quelques thématiques importantes pour ce domaine, telles que la tradition, l'intériorité et le groupe, sont problématisées. À partir du travail sur les chants traditionnels et d'expériences de l'auteur en compagnie Grotowski, le texte s'interroge sur le sens de la pratique artistique. Mots-clés: Workcenter of Jerzy Grotowski and Thomas Richards. Performance. Théâtre. Chants Traditionnels. Grotowski. 
Não tenho saudades do passado. Minha família vem da zona rural e sei que, até algumas décadas atrás, as condiçóes de vida eram brutais. Muitas crianças morriam antes de seus pais, a idade adulta e a velhice chegavam rapidamente; aos quarenta anos, era-se velho. Por uma razáo ou por outra, na parte do mundo em que nos tocou viver, aos quarenta há uma grande probabilidade de que estejamos na metade de nossas vidas. Para a maior parte da humanidade neste planeta, entretanto, esta mesma idade frequentemente coincide com a velhice e com a antecâmara da morte. Somos privilegiados, ao menos estatisticamente: temos mais tempo. Entretanto, enfrentamos o problema do que fazer com todos esses anos. É a mesma coisa como nos ensaios no teatro: você é um diretor, você cria as condiçóes nas quais pode trabalhar por três, seis meses com atores em um espetáculo e, com frequência, como observou Grotowski, depois das primeiras semanas você já não sabe mais o que fazer com os atores. A mesma coisa pode acontecer conosco na vida. Como vivê-la sem deixar que passe por nós e náo sabendo mais o que fazer com ela?

A pesquisa do Workcenter encarna um poderoso desejo. Não é nenhum tipo de nostalgia de uma Idade do Ouro mítica. Em alguns momentos raros da vida, quando um choque nos move, cada um de nós reconhece em si mesmo os sintomas de um desejo inominado, um desejo sem objeto, uma aspiração diferente da cadeia normal dos desejos, diferente da nossa percepção daquilo que gostamos e não gostamos. Possui relação com o pensamento sobre a morte. Somos sempre empurrados para a açáo pelo fluxo de desejos específicos, aceitos, desejos que se focam em objetos palpáveis, próximos ou distantes. Sem essa pressão seríamos inertes. Porém, quando o desejo é satisfeito e o objeto é conseguido, ficamos satisfeitos? Basto-me? Um ruído de fundo sempre permanece, um tipo de zumbido. É o som daquela força que se coagula em desejos que somos capazes de nomear, por objetos que somos capazes de segurar. Se você prestar atenção, não poderá evitar escutá-lo, não poderá evitar a percepção de que muitas das atividades com as quais ocupa seu cotidiano são somente tentativas de encobrir esse zumbido de fundo. Passamos nossa vida, consciente ou inconscientemente, tentando utilizar um sem-número de táticas para tapar nossos ouvidos a essa presença incômoda. Cale a boca. Cale a boca e deixe-me só, deixe-me em paz. E os anos passam. E passamos ao largo de nós mesmos. Somos capazes de tornar nosso o tempo que nos resta? 
Alguém perguntou sobre a diferença entre a vida real e o trabalho. Se eu não mentir para mim mesmo, quando é que minha vida é real? Quando me sinto real? E quando meu sentir é real? Estamos nas mãos de pseudocoisas. Dentro de mim há uma cavidade; deveria haver alguma coisa dentro, deveria haver eu, mas não há nada. Preencho o buraco com um sentimento vago, insubstancial. Embora obscuramente consciente de fazer, de existir, de ser, continuo sendo acidente. Apenas mais um acidente. No trabalho, existe um olhar sobre o indivíduo que pode parecer cruel, um olhar que tenta evitar as mentiras. Talvez sejamos acidentes nas correntes de todas as coisas. Porém, me atrevo a pensar que em cada momento se esconde uma possibilidade, um ato que pode nos abrir como se abre uma porta em cada campo de atividade humana, de relação, ali onde a cavidade é vislumbrada, a falta. O que resta então ao perceber essa ausência? Se consigo suportar essa descoberta impossível, o instante de lucidez se transforma em um desejo - de ser? Podemos dizer impiedosamente para nós mesmos que seres humanos são acidentes, com certeza. Todavia, mesmo nesse caso, como pertencer um ao outro? Como pertencer à vida? Apesar da cavidade. Para além da cavidade.

A pesquisa desenvolvida no Workcenter tem sido chamada de uma nova tradição. $O$ trabalho está enraizado em elementos performativos concretos e fundamentais. É legítimo identificar essa assim chamada nova tradição com os elementos básicos do trabalho teatral? De um ponto de vista muito específico, podemos responder afirmativamente. Podemos tratar os elementos de um trabalho diário, qualquer que seja ele, em constante relação com o que queremos que nasça e cresça dentro de nós, com o que queremos fazer com nossa vida. Qualquer práxis humana pode ser o fundamento de um trabalho sobre a vida. Náo falo metaforicamente, quero dizer trabalho sobre vida no sentido literal: a própria vida, um material como a madeira para o carpinteiro ou as sementes e as plantas para o jardineiro. Mas, em nome de quê há que se trabalhar sobre a própria vida? Onde está a necessidade? A vida já não é uma riqueza plena e perfeita, um presente, uma abundância? Às vezes, porém, sente-se que a vida é opaca, densa, em outras que ela é linda, luminosa, cheia de dons e surpresas e, mesmo assim, sentimos que toda essa riqueza esconde uma possibilidade ainda maior, um botáo esperando abrir-se para uma outra perfeição. Em ambos os casos, é como se a própria vida estivesse implorando para ser vivida em uma outra intensidade. Sim, 
ela - em outro lugar - é completa e não tem faltas, mas e eu? Onde estou eu?

Uma antiga história conta-nos sobre uma velha que vagueia pelas estradas do mundo, descalça, implorando por ajuda, em busca de seu marido perdido. Vamos considerá-la uma imagem da vida suplicando para ser vivida. O que acredito que seja o verdadeiro núcleo dinâmico do que aqui foi chamado de nova tradição não é tanto o domínio dos aspectos técnicos, mas antes o desejo de responder ao chamado da velha errante que vemos passar diante de nossa casa todos os dias, sem enxergá-la. Resgatar o simples. As técnicas são importantes, mas, antes e depois da técnica algo mais é necessário. Não confundamos técnica com ofício: este último inclui a primeira sem que seus limites coincidam. O fato é que se o escutar e o responder ao chamado da velha errante devem ser mantidos com alguma constância, necessita-se de algum tipo de base. Atualmente não vejo outro ponto de partida senão a impecabilidade profissional. Para que alguma coisa seja possível, é necessário o esforço de um trabalho bem realizado. Por outro lado - quem sabe? - o mundo é vasto, visto a partir da nossa escala, ele é quase infinito, então, quem pode realmente dizer? Contudo, não há dúvida de que o tempo de que dispomos não é infinito. Não podemos nos dar ao luxo de desperdiçá-lo.

Trabalhamos em um campo bastante tangível. À maneira de camponeses, de acordo com as estações, dia após dia. O campo é o terreno das artes performativas: um ofício. Náo ofício pelo ofício, mas como suporte de algo que não é simplesmente a competência profissional. Ao inverter a perspectiva, poderíamos dizer que o campo é o ser humano e que as ferramentas com as quais operamos nesse campo são os meios das artes performativas. A arte, no sentido mais amplo, pode ser veículo de milhares de coisas. No Workcenter, a arte é o veículo de um trabalho sobre si mesmo: o itinerário é o de uma possível transformação pessoal. Transformação não no sentido teatral (como, por exemplo, a do ator que transforma seu comportamento no comportamento do personagem); antes, a transformaçáo na qualidade de habitar de um ser humano no mundo, entre outros seres humanos. Ela ocorre dentro, mas está em relação direta com o que acontece do lado de fora. O trabalho sobre os cantos e sobre Ações criadas em torno dos cantos como instrumentos pode permitir ao atuante encontrar o espaço para uma mudança de qualidade em sua presença: na percepção do mundo e de si mesmo no mundo. 
Somente se compreendermos que a técnica não é meramente um procedimento mecânico poderemos considerar essa abordagem, essa assim chamada nova tradição, como sendo uma técnica complexa - um trabalho com instrumentos específicos, orientado para uma transformação concreta do atuante, por trás da qual está uma intenção bastante pessoal e íntima. Pode essa intenção, essa aspiração estar também presente em outras abordagens, em outras maneiras de lidar consigo mesmo? É evidente que a resposta só pode ser sim. Seria absurdo pensar que seres humanos pudessem esforçar-se para trilhar essa estrada exclusivamente em um único campo de atividade. Porque, fechando o círculo e trocando novamente de perspectiva, o veículo não é a arte, mas a vida mesma.

Esta última afirmação pode soar excessivamente romântica: poderíamos dizer que a vida diária contém imponderáveis demais, muito espaço para improvisaçáo - embora seu conteúdo seja a base integral e material do veículo. Estou tentando dizer que a aspiraçáo a que aludi previamente exige um enquadramento articulado. Articulado, por exemplo, do ponto de vista do ofício. Ao mesmo tempo, estou tentando dizer que o enquadramento do ofício não é suficiente. $\mathrm{Na}$ arte como veículo existem opuses. Sáo as opuses, em si mesmas, os instrumentos da arte como veículo? Eu não sei. Sei que no trabalho a que nos dedicamos elas são uma condição, mas não a única condição.

O Workcenter não é um monastério, não tanto pelo fato de não estar imerso em um contexto religioso (podem haver monastérios não relacionados a uma visão religiosa específica do mundo), mas do ponto de vista de seu funcionamento. A vida monástica é governada por um estrito sistema de regras, e poderíamos dizer que é precisamente por causa desse aspecto que um monastério é, virtualmente, um instrumento de trabalho sobre si mesmo. Na vida monástica, todos os atos da existência, dia e noite, desde os considerados mais banais até os que são vistos como os mais nobres estão organizados em uma partitura regulamentada e ininterrupta. Dentro desse enquadramento perfeitamente trabalhado pode-se renunciar conscientemente à pretensão da escolha e procurar pela liberdade. É como se, uma vez estabelecidas as condições exteriores, a atenção estivesse livre para voltar-se para o funcionamento interior e para as motivaçóes do comportamento exterior. Igualmente, se observarmos pessoas que vivem num ambiente ainda genuinamente rural, veremos que suas atividades são determinadas por necessidades orgânicas (es- 
tações, nascimentos, animais, mortes, semeadura e colheita, tarefas a realizar). Se eles negligenciarem alguma coisa, pagarão por isso no inverno seguinte. Muitas circunstâncias exteriores são fixas, em longos ciclos de tempo que se sobrepóem. No mundo industrializado, ao contrário, as circunstâncias exteriores são segmentos de tempo nitidamente regulados pelos ponteiros do relógio. Tempo pago e tempo livre. Tempo vendido e tempo ainda à venda.

Há em Action dois ou três fragmentos sobre os quais começamos a trabalhar em 1987. São, ainda, as mesmas açóes, as mesmas estruturas, os mesmos cantos. Mas, como são diferentes agora! $\mathrm{O}$ que você faz durante anos, dia após dia, pode crescer. Você pode crescer nisso e isso pode crescer em você. Chamamos investigação àquilo que fazemos, porque isso é investigação. Uma investigação metódica. Sobre o mesmo ponto. $\mathrm{O}$ trabalho avança porque permanece no mesmo ponto e não se move. Se mudássemos constantemente os instrumentos e seus focos de aplicação, seríamos um bando de vagabundos. Em vez disso, nosso trabalho opera através de repetições. Não a repetição de uma forma. É o fazer vivo, repetido em ciclos temporais de distintas amplitudes (desde a modalidade repetitiva, cíclica dos cantos vibratórios, até o trabalhar em ciclos de vários anos sobre a mesma obra), que torna possível a exploração. É isso o que faz do trabalho uma investigação. Pode-se explorar em profundidade, ou deslizando sobre a superfície, pela extensão. A maneira pela qual trabalhamos com Grotowski e depois sem ele tem sido sempre a primeira. Grotowski chamava a segunda maneira a do turista: assim que a excitaçáo de nervos provocada pela novidade desaparece, passa-se a outra coisa. Mas, um experimento só é significativo se estabelece as bases para um outro passo adiante.

Consideremos One breath left: cada versão foi o estágio posterior de desenvolvimento de um estágio anterior, tanto do ponto de vista do trabalho do ator quanto do da dramaturgia. Nosso próximo passo na fase completamente nova do projeto The Bridge: Developing Theatre Arts, isto é, Dies Ire, também estava voltado para um maior desenvolvimento, que se articulou na criaçáo de um evento teatral inteiramente distinto de seu ponto de partida. O salto de One breath left para Dies Ire foi motivado pelo fato de que One breath left havia atingido um nível muito complexo de composição, mas não continha em si mesmo a verdadeira semente de um desenvolvimento interno. Querendo continuar aquele trabalho, tivemos entấo que encontrar o 
meio de explodir a dramaturgia existente. Entretanto, náo foi uma mudança brusca e inesperada. O desenvolvimento já estava no ar, já flutuava ao redor do trabalho há bastante tempo. Sentimos que havia algo desconhecido querendo revelar-se.

Por outro lado, pensar que a honestidade para consigo mesmo e com o trabalho estaria por si só na pura e simples repetição é enganoso. Assim como é enganoso pensar que a honestidade consistiria em estar sempre fazendo algo novo e diferente. Para aqueles que já conheciam nosso trabalho, One breath left foi uma surpresa. Imagine: trabalhamos durante anos em Action, uma estrutura performativa para a qual apenas algumas poucas pessoas eram convidadas, em pequenos grupos, na sua maioria profissionais, atores, diretores, acadêmicos de teatro, antropólogos. Então, a certa altura, começamos a convidar náo apenas profissionais, mas quem quer que desejasse ver Action, ainda em pequenos grupos, simplesmente de acordo com a disponibilidade de lugares. E imediatamente: "Mas o que está acontecendo? As coisas mudam. Oh, que perigo". Aparece, entáo, um trabalho como One breath left, no qual deixamos entrar na sala, digamos, sessenta pessoas. Outra surpresa: elas compram ingresso. E seguimos assim. Porque o trabalho náo é um prédio feito de tijolos e cimento. Ele muda. Perguntamo-nos o que é necessário de dentro do próprio trabalho, o que sentimos que seja necessário para o ano seguinte, mesmo que aquele desejo pareça escandaloso. Buscamos em cada momento onde colocar o pé para dar o próximo passo. Nada é previsível. Há ciclos de necessidades que correspondem a períodos de fechamento e de abertura, sístoles e diástoles. Às vezes, é preciso agir e quebrar uma tendência cristalizada, às vezes não fazer nada $\mathrm{e}$ simplesmente seguir.

Grotowski raramente falava explicitamente sobre nosso trabalho como de uma tradição. Às vezes ele o fazia, sim, quase sempre em conversas pessoais, mas raramente durante o próprio trabalho. No trabalho, era quando a força da palavra podia atuar como um catalisador, como uma faísca sobre material combustível. Se o fogo não pega imediatamente, a faísca é perdida, e então há que encontrar outra ponte para cruzar a distância entre dois mundos, dois universos que são as duas pessoas que estáo ali, presentes sobre a base de um acordo comum, não explicitado, nutrido pelo desejo de superar os próprios limites. Quando trabalhamos com material incandescente, fluido, quando não há tempo para muitas palavras (exatamente por- 
que o material não pode esfriar) e te dizem: "Do not identify with the teacher but with the teaching" ${ }^{2}$, entâo, de repente, lampeja dentro de você uma intuição, de algo que pode existir independentemente de você, e isso dá outra dimensão a seu trabalho com aquela pessoa. Seu trabalho não é apenas entre você e ele. Você e ele morrerão. Há alguma coisa que não morrerá? É apenas uma pergunta, mas, como eu disse, ela dá outra dimensão ao seu trabalho daquele instante, ao seu acordo não explicitado. Isso significa que aquele ensinamento também pode existir para além de você? Eu passarei, você passará, e posso dizer que esse assunto não me diz respeito; não há dúvida de que eu náo estarei lá - a morte varrerá todo o meu passado. No presente, porém, esse alargamento de dimensóes importa.

O que está em jogo não é um certificado de autenticidade, não é uma carteirinha de membro de alguma instituição que existe fora de você. Grotowski tinha a natureza, ou o destino, de alguém extremamente livre. Podemos pensar o que quisermos de sua relação com a sociedade, com o teatro, com a política. O que salta aos olhos ao olharmos para sua vida, ou ao conhecê-lo, é uma profunda, quase desesperada, atração pela liberdade, a pergunta: é possível ser livre? Não se identifique com o professor e sim com o ensinamento. Essa pergunta, mesmo não respondida, abre um outro horizonte.

Uma analogia: tomemos o caso de Simone Weil. Ela sentia uma profunda atração pelo mundo cristão primitivo e pela figura de Cristo. Em sua correspondência com um padre católico, podemos ler sobre suas motivaçóes e dúvidas. Ela nunca quis ser batizada. Dizia que sua função como intelectual exigia que ela permanecesse livre, à margem. Isso é apenas uma analogia. Autonomia, não recusa ou negação; antes, renúncia a uma posição de estabilidade, certeza, falta de dúvida. A certeza náo é criativa, nem para um intelectual nem para um artista.

Mencionei as conversas com Grotowski, quando falávamos frente a frente, a sós. É tarde, você está cansado, amanhã de manhã você tem de trabalhar, mas o velho senhor está com vontade de falar e a conversa pode galopar até atingir longínquos horizontes, prosseguindo em direçôes inesperadas. Em alguns momentos ela parece estagnar dentro de você. Você se sente sonolento e pesado. Então, de repente, chegamos a algum ponto, você encontra o que está em seu coração e as palavras para expressá-lo. Às vezes, falávamos sobre tradição e as tradiçôes; foi Grotowski quem sugeriu que eu estudasse 
o mundo indiano. Entre os séculos XIX e XX, o conceito de philosophia perennis (em sânscrito sanātana dharma, a Tradição atemporal, com maiúscula) estava na moda entre esotéricos. Uma ideia bastante suspeita. Às vezes falávamos sobre tradição, sim. Nem uma múmia a ser adorada, nem uma nebulosa sociedade secreta que fornece um certificado. Em vez disso: o que está vivo entre você e eu? Estamos à cata de palavras para falar sobre algo que existe em você, em mim, entre nós e além. Existe alguma coisa que não esteja nas mãos do tempo? A essência do trabalho te dá a esperança de que possa haver um sentido no que você está fazendo, mesmo que você vá morrer. Às vezes, você pensa: já que vou desaparecer, para que serve tudo isso? Por que toda esta labuta, todos estes esforços, todas estas coisas para fazer? Em todo caso, tudo acabará, perecerá, passará. O que ficará? E nada parece fazer sentido.

Grotowski me contou uma história: um deus encontra-se encarnado, sob forma humana. Porém, no curso da viagem de sua morada original para o novo destino, ele esquece sua origem. Um homem ajuda-o a recordar. $\mathrm{O}$ deus gasta anos de aprendizagem apenas para lembrar, finalmente, que ele é um deus. Oh, ele é deus! Mas então, se ele é deus, qual é o sentido de todas essas batalhas, grandes e pequenas, de todos os prazeres experimentados e dores suportadas, do mundo inteiro mesmo? O homem que o tinha ajudado a relembrar diz: "sim, é como um sonho. Contudo, vá. Vá e dance através desse sonho como se fosse sua única oportunidade. Atue, atue inteiramente, como se fosse tudo real. Atue seu papel com absoluta paixão e permaneça livre". Para mim, essa história tem muito mais a ver com tradição do que qualquer certificado de ortodoxia ou pertencimento.

Ao dizer investigação pura podemos pensar em algo hermético, impermeável. Isso é uma abstração. Náo há nada puro no mundo. Às vezes, pode-se criar um espaço protegido que parece ter sido separado e isolado. Nada no mundo, porém, está separado do que quer que seja, nada é impermeável. Não podemos sair do mundo. Podem-se escolher, até certa medida, quais influências externas deixar entrar livremente, a quais resistir, mas náo podemos construir compartimentos estanques. Perguntam-nos: "que relação vocês têm com o mundo real?” Ora, sejamos lúcidos: às vezes é a própria existência que não parece ser tão real. Há momentos em que sentimos como se a vida fluísse. Ela ri, salta, dança loucamente, forte como a natureza. Em outros, é como se faltassem peças. Não se está inteiro, não se 
está pleno. Sentimo-nos irreais, e essa sensação também é parte da realidade, não é? Trata de uma coisa pessoal, admito. Mas, devemos estar conscientes de que as paredes não são impermeáveis. Há seres humanos aqui, e em outro lugar, náo muito longe, também há outros seres humanos. Alguma coisa passa por entre as paredes e por entre os seres humanos.

Em muitas tradiçóes ligadas ao que podemos chamar de interioridade existe um movimento que luta contra a natureza com as forças da própria natureza. $\mathrm{Na}$ prática, uma pessoa dotada de certo discernimento, certa experiência, lança um desafio. Em torno dessa pessoa se cria uma espécie de movimento centrípeto, e outras pessoas que estáo à procura aceitam o desafio. $\mathrm{O}$ que acontecerá a esse movimento após, digamos, três geraçôes? É uma coisa que está para além de nossas possibilidades e de nossas preocupaçóes. Náo creia em nada, apenas experimente e veja por você mesmo. A luta contra a tendência inevitável à descida pode acontecer somente dentro de nós mesmos. Uma luta contra uma máquina infernal, de cuja operação náo se pode escapar. Há um grande rio com uma corrente muito forte. Seu poderoso fluxo corre em uma direçáo. Ele desce a montanha, para baixo. Tente retornar para cima, em direção à fonte.

Tenho visto ultimamente muitos grupos de teatro procurando por cantos antigos, textos antigos, danças antigas que eles tentam utilizar em seu trabalho. Procuram, nesses elementos, por uma fonte. Procuram algo autêntico e nessa busca eles se voltam para formas arcaicas como se essas contivessem uma resposta. Mas, onde estáo as fontes antigas? Todos concordamos: aquilo de que necessitamos não é arqueologia, mas água viva. Mesmo sabendo que, no fundo, esconde-se uma fonte borbulhante, como encontrá-la e mantê-la fluindo? E então, o que fazer com aquela água? Quem sabe seja necessário encontrar alguém que possa ajudá-lo, criar solidariedade entre pares para que sigam a busca juntos? Um professor? Se o professor te escolher, você pode dar-se a ele como se mergulhasse numa fonte. Ele também precisa de água viva. Você é a água viva dele. E ambos são a fonte. Alguma coisa entre dois seres reconhece-se a si mesma. A sua imagem e semelhança. $\mathrm{O}$ gêmeo, dois gêmeos.

As fontes antigas somos nós. No momento em que a força da vida dentro se torna incandescente, um se torna um espelho para o outro. Aceitar-se a si próprio através do outro, um ser humano. Eu exijo algo de você, eu peço para que você lute por sua humanidade, 
e você exige o mesmo de mim. Sozinhos, trabalhamos, fazemos, pensamos juntos. Eu exijo de você porque você é meu irmão, é minha irmã. Fazer um esforço, náo perder tempo. Não se iludir a si mesmo.

Grotowski morreu e em um bom momento. Ele viveu até a sua morte. Desde a fundação do Workcenter, poucas pessoas souberam que ele estava doente, e táo gravemente que podia ter morrido a qualquer momento. Era um fato simples, um elemento da vida cotidiana. Assim, a vida cotidiana mesma era um contínuo estado de emergência. Porque Grotowski tinha uma intenção. Durante uma conferência em Florença, no fim dos anos 1980, alguém lhe perguntou o que ele estava planejando fazer e ele respondeu: "quero fazer um ovo. Sou uma galinha que tem que pôr um ovo". Ele não deu maiores explicaçóes. Ele estava se referindo ao que já havia começado a fazer, e que náo consistia no treino de um ator ou de um diretor ou de um estrategista, coisas que ele já tinha feito no passado. Grotowski queria passar para uma única pessoa aquilo que ele denominou mais tarde de aspecto interior do trabalho.

A água começa a ferver de repente, mas esquenta gradualmente até o ponto de ebulição. Durante aqueles últimos anos, Grotowski estava indo em direção ao ponto de ebulição. Ele sabia que tinha pouco tempo e nós também sabíamos. Ele foi em direção ao ponto de ebulição de uma vida humana de modo lúcido, ativo. E quando ele morreu, o trabalho continuou. Não houve grande mudança no trabalho após sua morte. Grotowski tinha preparado essa transição longamente. Cada dia daqueles anos foi um passo em direção à sua ausência. Ele não gastou o tempo que tinha ensinando um sistema de regras a serem respeitadas por certo tempo ou um conjunto de princípios. Cada vez que caíamos na armadilha de transformar algo que ele havia dito numa regra universal, ele nos sacudia desse conforto, que não tinha absolutamente nada que ver com o que ele estava tentando indicar: um caminho para a autonomia. Ele também indicou que não havia caminhos abertos naquela terra e que não havia mesmo uma única estrada. A cada dia, uma caçada. A cada dia, você tem que descobrir em si mesmo o inimigo e o aliado.

E então: E depois de Grotowski? Nisargadatta, ao ser perguntado se seguia as pegadas de seu guru, respondeu: "não há pegadas, pois meu guru não tem pés".

Não estamos seguindo um caminho já traçado. Abrimos nossa própria estrada, se uma estrada é possível e necessária. Quando a 
arte, como era a intenção de Grotowski, serve a um trabalho sobre si mesmo, alguns aspectos tradicionais podem estar presentes, por exemplo, a relação professor-aprendiz. Mas, como o próprio Grotowski escreveu, uma tradição pode viver somente se a nova geração vai além da anterior. Uma investigação. Ou seja, uma exploração onde não existem mapas.

Faça alguma coisa. Faça como puder, com honestidade. E melhor do que puder. Faça melhor do que acha ser possível para você. Mova este peso, este muro de impossibilidade para um pouco mais adiante. Expanda seus limites da perspectiva de seu ofício, não para dar escape à sua frustração, mas como um guerreiro o faria, com consciência, coerência e fluidez. Então, talvez, seu trabalho seja útil. Já fui perguntado se pode ser útil ou perigoso para um jovem ator ver o que fazemos. Disseram-me: Estou preocupado porque jovens atores que veem o trabalho sobre a arte como veiculo podem tentar fazer o que vocês fazem, imitar as formas... Eu realmente acho que, por esta razáo, pode ser arriscado para eles ver o que vocês fazem. Que bobagem! Não existe arte na segurança. Mas, deixemos a arte de lado, essa palavra enorme, e falemos simplesmente de ofício, de artesania. Nosso trabalho como artesãos não é seguro. Fazer significa arriscar. Arriscar a derrota, arriscar a vitória. Talvez a única coisa que se possa dizer para um jovem ator ou diretor é: não dê ouvidos a quem lhe fala sobre os perigos a evitar. Faça o que você quer, o que você deseja, profundamente, o que você percebe como necessário. Siga seu próprio caminho, e, no final, caberá à vida decidir se você realmente fez alguma coisa ou apenas se iludiu a si próprio. Quem dirá que você perdeu ou venceu? Os críticos de teatro? O público? Você tem uma vida; coloque-a na mesa e jogue. Se quiser assumir um risco, assumao - está em suas mãos. Náo jogue os velhos jogos de outras pessoas, invente seu próprio jogo. Se um jovem ou uma jovem começa a vida castrando-se a si próprio, dizendo para si mesmo: não, isso eu não posso fazer, aquilo eu náo posso fazer irá para lugar nenhum. Muitos já lhe dizem e sempre lhe dirão você não pode... Suas próprias mentes lhes dizem você não pode... Porém, a verdadeira aventura começa quando eu desafio meu coração, meu corpo, minha mente a fazer o que eu não posso fazer. Siga seu caminho, lute sua batalha. Ninguém será capaz de dizer se você venceu ou perdeu até o último momento, o instante em que estiver solitário, diante do desconhecido.

Quando alguém que tem experiência no trabalho que fazemos começa a cantar, podemos dizer que ele chama o canto. Esse cha- 
mado é específico, isto é, é uma ação em si mesma. Está relacionado a uma intenção, àquilo que ele quer fazer. E, portanto, a uma eficácia que é possível, mas ainda assim não é buscada. Não a eficácia, mas o canto tem de ser procurado enquanto se canta, pois o canto não pode trabalhar por si mesmo. Tem de haver uma investigação ativa levando você de um impulso a outro. A pessoa se aproxima do canto - cuja melodia e ritmo são sempre precisos - não como se ligasse uma máquina: eu aperto o botão, e então: ah, funciona! Mesmo com uma máquina, para ser honesto, você nunca pode estar completamente seguro, mas digamos que você pode razoavelmente esperar que a máquina comece a fazer o seu trabalho. Com os cantos a coisa é bem diferente. Digamos que Helene está ali na sala de trás, onde nós fizemos nossa pausa; estamos todos esperando por ela para recomeçar. Alguém chama: Helene! (isto é uma ação, não é?). Talvez ela escute e venha, talvez ela não ouça. Talvez ela ouça, mas náo queira vir. Claro que a aproximação ao canto não é exatamente como chamar Helene na outra sala, mas podemos dizer que a pessoa que entoa o canto chama, realmente como se estivesse chamando alguém. Não é uma questão de procurar sentir-se vivo. Para sentir-se vivo, podemos fazer uma festa ou coisa parecida. Aqui, poderíamos dizer, em uma linguagem muito pessoal que, com o canto, convoca-se a própria vida e, consequentemente, a minha vida, a sua vida, como se perguntássemos a essa substância delicada, mas palpável: por favor, levante-se e brilhe. Como quer que eu cante? Evocê, companheiro: estou indo, você vem comigo?

Como pode ver, isso são açôes. E açôes estão sempre ligadas a motivaçóes. A canção chegará? Meu parceiro virá comigo? Não podemos saber. Mas você sabe o que está fazendo. Eis aí o drama, o conflito dramático, o ágon. E, ao mesmo tempo, a possível eficácia. Vamos lá! Será que faremos algo acontecer entre nós? Será que vamos subir? E, sim, há algo acima, além do conflito dramático. Uma possível resolução do drama.

A queda de obstáculos e a chegada do canto podem ser percebidas como uma grande dádiva. Às vezes, a dádiva aparece por alguns dias, e depois você luta por semanas ou meses para encontrá-la de novo. Ou ela pode durar por algum tempo. E, entáo, por alguma razáo misteriosa, quando a pessoa começa a cantar, imediatamente a canção torna-se viva, o espaço ao redor começa a brilhar. Tudo o que a pessoa faz é evidente, claro, transparente e orgânico. 
Recordo-me de um período de trabalho, mais ou menos um ano depois de começar a trabalhar no Workcenter, durante o qual eu tive a impressão (sem dúvida uma impressão completamente pessoal, uma associaçáo, como se diz) de que certos cantos, especialmente os cantos nos quais trabalhávamos com mais profundidade eram seres vivos, como pessoas. Era uma coisa ligada a primeira infância. Aí um canto era um homem, outro uma mulher, outro um cachorro grande e faminto. E cada uma delas parecia um pouquinho diferente a cada dia, exatamente como uma pessoa, e sem que se mudasse a melodia. Havia toda uma série de coisas que eu achava que não devia fazer aos cantos porque eles ficariam - como dizer - de algum modo, irritados comigo. Se ela se irritar comigo, quando eu chamá-la, ela não virá. E talvez ela fique rancorosa por alguns dias ou por semanas. Entende? Não se tratava da criação de um bizarro sistema de crenças, era parte de um processo de descoberta, apoiado por associaçóes pessoais e subjetivas, relacionadas à experiência da infância. Não se transformou em um hábito, em algum tipo de superstição. Era uma estação do trabalho, uma estação pessoal.

Aquele canto era como uma mulher com quem se poderia casar: ah, você poderia casar com um canto e ser fiel a ele, ou traí-lo. Com o tempo tudo isso mudou e, ainda assim, de algum modo, permanece aí. Sei que, a cada momento, tenho a opçáo de permanecer fiel àquela alegria ou de traí-la, em relação à minha consciência. Tenho que saber o que faço. De novo: é realmente o canto o que importa? Sim, aquele canto preciso. Mas, é realmente o canto que importa? Não, o canto mesmo não tem importância. Se ele encontrar um espaço dentro de você que não estiver obstruído, um espaço no qual alguma coisa possa crescer e nutrir o trabalho a ser feito, aí sim ele é importante.

Em 1986, logo depois de começar a trabalhar no Workcenter (eu fui convidado por três semanas, depois da seleção), os assistentes de Grotowski disseram-me para preparar uma acting proposition, uma pequena proposição baseada em alguma canção que eu conhecia da minha infância. Foi um desastre: na análise que se seguiu à apresentação, a única coisa que eu entendi (Grotowski falou em inglês e, na época, eu não entendia uma palavra desse idioma) foi que o que eu tinha feito era verdadeiramente horrível. Entretanto, também assisti às apresentaçóes de outras pessoas e intuí uma possibilidade. Assim, preparei outra proposição e, depois da apresentação, entendi 
que estava na direção certa, pois Grotowski disse "Bom" e deu a Thomas a tarefa de trabalhar comigo. Então, começamos a elaborar aquela proposição e trabalhamos bem juntos. Mostramos o trabalho a Grotowski, que nos disse que estávamos no caminho certo e que devíamos continuar trabalhando. Depois de uma ou talvez duas semanas (a essa altura eu tinha sido convidado a permanecer por mais três semanas) apresentamos um pequeno trabalho novamente. Recordo que em certo momento daquela estrutura eu virava as costas para os observadores (Grotowski, seus assistentes daquela época e mais dois ou três participantes como eu). Enquanto eu trabalhava, repentinamente uma voz cortante disparou: "Pseudoemoçóes! Nada de pseudoemoçôes! Isso são só pseudoemoçôes!” Era Grotowski. Tentei seguir. Náo entendia nada do que ele estava dizendo. Que diabos é uma pseudoemoção? Eu estava confuso. Mas ele tinha razão. Você vê, como por milagre, eu tinha conseguido fazer alguma coisa durante algum tempo. Depois de alguns dias, comecei a observar o que estava sentindo, o que estava fazendo e, pronto, náo fui mais capaz de fazer coisa nenhuma. Estava apenas tentando criar uma certa atmosfera e não estava fazendo nada. Tinha substituído as ações simples pelos seus resultados, poderíamos dizer.

Emoções, então. Como seres humanos, somos dotados de um aparato muito sensível para ler as emoçóes e intençóes nos outros. É mais difícil lê-las em nós mesmos. Esse aparato também funciona eficientemente quando vemos um ator no palco e, também, por exemplo, quando observamos um devoto que participa de um ritual religioso. Instantaneamente, acreditamos nele ou não e nossa percepção não tem nada a ver com gosto pessoal; nós não escolhemos. Às vezes, quando não acreditamos neles, vemos fluindo neles (ou melhor, sobre eles) o que podemos chamar de pseudoemoção - uma reprodução autoconsciente e superficial de um sentimento verdadeiro, algo encenado pela mente.

Em vez disso, vejamos: uma pessoa está cantando e ela canta de modo vivo, descobrindo a cada momento como procurar pelo canto, como segui-lo. O corpo busca, em impulsos, junto com a mente, junto com o coração. A pessoa procura sem auto-observaçáo (que é um caminho direto para a pseudoemoção). De repente, ocorre um deslocamento: agora, é como se o próprio canto estivesse procurando pela pessoa. É estranho dizê-lo, mas é assim que eu percebo. O canto procura por ela ou por alguma coisa nela. Agora já se torna difícil 
distinguir entre canto e processo. Sim, o canto, nutrido pelo processo, torna-se um caminho, o caminho para casa, procurando por essa centelha escondida na pessoa. Se você observá-la, verá que, enquanto ela canta, um intenso processo psicofísico atravessa-a, o qual pode assumir muitas formas e articular-se em um fluxo ininterrupto de impulsos. Olhando, você não consegue distinguir onde um impulso termina e o próximo começa. Porém, tudo é claro e evidente, nada é caótico, nada é gratuito. Para você, como observador, isso desperta inúmeras associaçóes. Parece-lhe que muitas pessoas - ou distintas profundidades dentro da mesma pessoa - estão sutilmente subindo à superfície, uma após outra. Às vezes, de fora, você pode perceber que a pessoa está passando por uma experiência emocional fortíssima, mas você também sente outra coisa, que não há identificação, nem o agarrar-se à emoção. Aqui, não há pseudoemoçóes, a pessoa sabe o que está fazendo e o que aparece é antes uma força que leva e transporta e que necessita de um canal solidamente construído. Exatamente porque se trata de uma força, os elementos estruturais têm de ser rigorosos, articulados, incorporados; sobretudo as intençôes, evidentemente. Mas, a própria canção é um elemento estrutural. A melodia é precisa, afinada, o ritmo é preciso, a letra é precisa. Além dessa, outra categoria de elementos estruturais é o que podemos chamar de regras do jogo. Por exemplo: um de nós conduz a canção e os outros seguem; o líder não improvisa, nem a melodia nem a letra da música, e sim trabalha dentro de uma estrutura precisa. Aqueles que estão seguindo têm de ajustar-se a micro oscilaçôes de tempo-ritmo e constantemente modular a afinação seguindo o líder. $\mathrm{O}$ que significa que devem cantar mais suavemente do que ele. Eles precisam permanecer conscientes em relação ao que está acontecendo e estar prontos para reagir. E reagir de um modo que auxilie e náo perturbe. Há muitas regras para o jogo e todas elas incluem todas as coisas que não se deve fazer.

Nas Açóes, é possível observar um tipo tradicional de movimento, um modo específico de caminhar que alguém poderia considerar como uma dança, mesmo que isso fosse enganoso no contexto do nosso trabalho. Nós a chamamos de uma caminhada ou, pelo seu nome haitiano, yanvalou. A forma é específica, uma forma-em-movimento, extremamente orgânica, que pode levar anos para que se adquira a mestria. Pode-se aprendê-la como uma forma e então trabalhar procurando por sua função. Grotowski dizia que 
o yanvalou é um "mantra para o corpo", fazendo uma analogia com formas repetitivas de oração. É um fluxo orgânico e estruturado que pode ser encarado como uma ferramenta para o trabalho interior. Se você examinar essa caminhada com atenção, perceberá que ela é, ao mesmo tempo, extremamente simples e complexa. Os passos são simples. Primeiro o calcanhar toca o cháo, o deslocamento de um pé para outro é controlado e a coluna reage suavemente ao contato do pé com o chão. Enquanto o pé toca o chão, um suave impulso sobe ao longo da coluna. Quando o pé se ergue do chão, alguma coisa na coluna descende. Os dois movimentos, subindo e descendo, formam juntos um círculo com duas breves suspensôes no zênite e no nadir.

Se a caminhada for executada corretamente, ela funcionará por si só? Náo sei, mas duvido. Com certeza, a resposta depende do que se quer dizer com corretamente. Estou convencido de que há elementos técnicos que podem funcionar como uma base para a prática interior, mas seres humanos são máquinas complexas (e, máquinas, já é uma palavra errada, os seres humanos são misteriosos). Muitas vezes reagimos a estímulos internos e externos como se alguém tivesse apertado um botão e não houvesse nada que pudéssemos fazer. Você me chama de idiota e eu me irrito. Você diz que sou inteligente, sensível e criativo e eu desfruto alegremente de nossa conversação... É automático. Mas, a possibilidade de alguma coisa que ascende no ser humano - esta coisa sutil que reúne conteúdos psíquicos e presença corporal e o que vive na carne, no intelecto e nas intençôes - será que é governada pelo automatismo? Talvez existam leis que possam ser isoladas, mas elas me escapam. A caminhada orgânica a que me referia, um pouco antes, começa a funcionar quando alguma coisa dentro e ao redor é realmente abandonada e outra coisa então ascende. O que é isso que está sendo abandonado? O que é que ascende? Eu não sei. Porém, alguma coisa é abandonada, alguma coisa se desarma e se rende para que uma outra coisa possa ascender e entáo descer de volta e lavar todo o ser. De fora, pode-se perceber que agora o yanvalou já não é apenas o movimento de um corpo que caminha. Você pode sentir as marcas disso em você. Agora, há evidência, alguma coisa na pessoa começa a brilhar, a estar presente. Está cheio da vida, dos desejos, da intimidade daquela pessoa. E, ao mesmo tempo, algo que não é pessoal ascende e desce. A pessoa é um canal. O indivíduo com suas idiossincrasias e sua biografia não se dissolveu, não desapareceu, está antes a serviço de algo. 
Atuar... Quando sou perguntado sobre o que faço da vida, digo que sou um ator. Por outro lado, sinto que devo acrescentar mais alguma coisa. Às vezes o faço, em outras não. Durante anos, tivemos a proteção de um grande nome e alguém poderia dizer que crescemos como crianças mimadas. Eu sei, entretanto, que este trabalho é extremamente exigente. Sei que o que fazemos não é algo extravagante e autocomplacente, não é uma explosão de entusiasmo. Há riscos sutis que se decide correr, desarmando-se a si mesmo no meio da batalha, renunciando à proteção. Quando Grotowski falava em desarmamento no trabalho que se pode fazer no e através do teatro, ele não estava falando em renunciar ao ofício. Ele estava realmente se referindo ao ápice, ao nível máximo do ofício. $\mathrm{O}$ ofício pode se transformar em um tipo de arma, ou você pode usá-lo para tentar não esconder-se, não fingir. Para saltar uma barreira. Alguém pode considerar isso um luxo. Para mim, está relacionado com a urgência da sobrevivência.

Achar que o ator deva necessariamente atuar com fingimento e que aquilo que se faça deva ser falso, não real, é banal. Atuar pode significar simplesmente fazer. Certo tipo de ator procurará instintivamente ou conscientemente uma maneira de fazê-lo com verdade. Quando Grotowski dizia "neste momento de sua estrutura você deve rir", ele não queria dizer que você deveria fingir rir. Não, não, o desafio era que o riso fosse verdadeiro. Não é uma questão de contrair o diafragma e fazê-lo vibrar para produzir um certo sintoma, um certo som. Suas reaçóes devem ser sinceras e orgânicas. Você está diante de uma simples tarefa prática - uma tarefa quase impossível. Pode-se trabalhar nessa direção por meio de ações físicas pequenas, simples: tem-se uma partitura na qual as próprias intençôes e associaçóes estáo inscritas, e se alguém segue o tempo-ritmo dessa partitura, com todas as suas pequenas açóes precisas, existe então a possibilidade, por exemplo, de se começar a rir. Simplesmente, começa-se a rir. Não se trata de demonstrar suas próprias reaçóes, trata-se de fazer açóes simples e verdadeiras, e isso é tudo.

Quando se trabalhava com Grotowski, se havia um problema, imediatamente ficava claro: e então? O que fazemos? Grotowski não te dava a solução. Você poderia ficar sentado na sala dele durante duas, três ou sete horas formulando todas as soluções imagináveis, até chegar ao ponto em que nenhuma delas parecia factível, zero. Sua mente diante de uma parede. E então - quando todas as respostas possíveis 
tinham sido bloqueadas por serem impraticáveis, ilusórias, irreais naquele momento algum outro recurso apresentava-se, solução outra; não uma fuga, como uma formulação fácil ou crença simplista. Não creia em nada, por favor. Perceba, veja, julgue, não creia. Trabalhar com Grotowski era também esse outro tipo de impossibilidade, como uma espécie de koan, no qual uma pergunta parece não ter nenhuma resposta possível. No fazer, é a mesma coisa: naquele instante você deve rir, não produzir o som do riso, e sim desenterrar aquele recurso e permitir que viva aquilo a que chamamos emoçóes. Mas o que é uma emoçáo? É o que percebemos como uma vaga sopa de eu-gosto/ eu-não-gosto? Se for isso, não me interessa. Não desejo ver isso em uma obra de arte. É aquilo que o ator produz ao forçar e bombear? Também não me interessa. Qual é o lugar da emoção na arte?

Digamos que em certo ponto de meu registro devo sorrir. Digo a Grotowski: sim, entendi, mas naquele momento náo tive vontade de sorrir, pois ela (minha parceira naquele momento) não estava fazendo o que tinha que fazer, suas ações não estavam funcionando. Concordo, havia estes problemas, mas, Mario, qu'est-ce que ça te coûte de sourire? Depois, está trabalhando e, naquele momento, diante do mesmo velho problema, você se recorda daquele momento em que a solução apareceu repentinamente: sim, o que me custa? A memória acende o sorriso sem que nem você mesmo perceba. E é um sorriso de verdade, não demonstrativo, e seu parceiro vê e compreende.

O trabalho do ator pode ser verdadeiro. É claro que se pode considerar o teatro, com suas criaçóes mágicas, como pura ficção, mas uma alternativa também é possível. A mise-en-scène pode ser ficção e o trabalho do ator pode ser verdadeiro. E mesmo o trabalho do diretor pode sair do domínio do não real. Por outro lado, não há nada de ruim em atuar, o problema começa quando a qualidade é medíocre.

Trabalhamos duro, mas não se trata de tortura. Há um tipo de racionalidade no próprio trabalho. Sim, existe uma falta de complacência. Complacência em relação ao corpo, por exemplo. Às vezes o corpo deseja descansar, mesmo quando ele realmente náo necessita. Outras vezes, entretanto, você percebe claramente que tem de fazêlo descansar, mesmo que ele não o queira. A questão é não matar-se por meio do trabalho. Trata-se, antes, do contrário.

Assim, chegamos ao ponto de partida: o que queremos do trabalho artístico. A que aspiramos? Se buscamos algo como uma reve- 
lação, uma plenitude, uma liberdade, então devemos nos confrontar com o problema do ofício e da artesania para que nossas aspiraçóes sejam mais do que apenas ilusóes.

Quando cheguei ao Workcenter, eu não sabia nada sobre o passado de Grotowski. Mais tarde, quando o trabalho já havia decolado, tivemos muitas conversas sobre esse assunto. Muitas vezes, nos perguntam sobre a relação entre o Workcenter e o trabalho parateatral de Grotowski. É evidente que no Workcenter sempre existiu, desde o começo do trabalho em Pontedera, uma forte ênfase na competência artesanal. Sou fascinado pelos anos poloneses de Grotowski (os quais são, de fato, apenas relativamente poloneses, pois a partir de uma determinada época Grotowski viajou muito, sozinho ou com seus colaboradores, e conheceu e trabalhou com pessoas das mais diversas origens e culturas), os anos dos espetáculos teatrais, mas também os anos das fases seguintes, parateatro e Teatro das Fontes. A diferença entre os períodos pós-teatrais do Teatr Laboratorium e o trabalho atual aqui no Workcenter é analisada por Grotowski em Da Companhia Teatral à Arte como Veículo. Nesse texto, Grotowski menciona o risco de uma limitaçáo que ele encontrou durante aqueles períodos, a de "fixar-se no plano 'horizontal' (com as suas forças vitais, portanto, principalmente corpóreas e instintivas) em vez de decolar desse plano como de uma pista". E, a respeito da pesquisa do Workcenter, do trabalho sobre a Arte como veiculo, ele diz que "procura passar, consciente e deliberadamente acima do plano horizontal com as suas forças vitais".

Esse plano horizontal tem nele mesmo inúmeros níveis. No contato sem medo, uma vitalidade alegre pode fluir livremente. Não se trata apenas de uma exuberância da vida do corpo. Também pode manifestar-se como certa qualidade da vida psíquica. Grotowski chamou esse aspecto do plano vital de o jardim. Podemos ver uma manifestaçáo disso em certos sonhos extraordinários, vivos, cheios de cores. Um jardim fascinante, no qual todas as coisas, mesmo as mais banais, tornam-se como que mágicas: como se objetos estivessem vivos, animais falassem, como se mesmo o vento reagisse a você e a suas açôes. Esse lugar, esse nível de percepção é sedutor e, às vezes, criativo, mesmo sendo arriscado. Arriscado simplesmente porque é maravilhoso. Grotowski disse-me que ele pode lhe seduzir, e se você não prestar muita atenção, pode cair em uma armadilha. A mesma coisa é válida para o plano relacionado à exuberância da vida corporal. 
Grotowski dizia que é possível tentar ir, consciente e deliberadamente acima deste nível, em direçâo à verticalidade. Imagine suas faculdades, seus recursos, alinhados ao longo de um eixo central. Não em luta uns contra os outros, mas como se estivessem a serviço. $\mathrm{O}$ que está embaixo permanece embaixo e sustenta o que está em cima. Aquilo que é sutil e leve deseja reconectar-se ao que é sutil e leve, e mesmo fluir em direçáo de algo que pode ser vivido como a fonte mesma daquilo que é sutil e leve. O que é pesado e denso funciona como base e fundamento. Sei que essas palavras são estranhas. Metafóricas? Dentro de nós há muitas capacidades, muitas qualidades diferentes. Há abordagens à interioridade do ser humano nas quais essas qualidades podem ser alinhadas ao longo de um eixo.

Quando trabalhamos, vemos que um dado canto não pode estar em certo lugar da estrutura, porque aquilo que é chamado por ele bloquearia a linha de ação, não no sentido da partitura individual, mas em relação à continuidade do itinerário vertical. O critério de julgamento, portanto, não é de ordem estética. Aquele dado canto, por exemplo, poderia provocar certo desenvolvimento na percepçáo e experiência dos atuantes e levá-los à fixação em um nível de vitalidade que já havia sido ultrapassada em uma sequência anterior, na mobilizaçáo necessária para ascender. Esse nível de vitalidade, de exuberância vital pode ser muito intenso, extremamente evidente, performativa e subjetivamente interessante, mas aonde chegará se ele mantém a predominância? Se for encontrada uma passagem desse nível vital para o que é mais sutil, então algo leve aparecerá, algo que poderia mesmo passar desapercebido. Algo que não se impóe à percepção de uma testemunha, mas que, entretanto, pertence ao domínio do perceptível, como o faz um silêncio sutil.

Uma história conta que, enquanto se escondia na caverna, Elias escuta uma voz o chamando. E eis que o Eterno passa por ali e um poderoso vento arranca as montanhas e parte as rochas em pedaços diante do Eterno, mas o Eterno náo está no vento. Depois do vento, um terremoto, mas o Eterno não está no terremoto. E depois do terremoto, um fogo, mas o Eterno não está no fogo. E depois do fogo vem uma voz como um silêncio sutil. Ouvindo-a, Elias cobre o rosto com seu manto, e sai para ficar na entrada da caverna. E eis que vem a ele uma voz que diz: "que fazes aqui, Elias?". 


\section{Notas}

${ }^{1}$ Este artigo foi publicado pela primeira vez sob o título de Desiderio senza oggetto em Opere e sentieri, Volume I, Il Workcenter of Jerzy Grotowski and Thomas Richards. Foi transcrito e editado por Lisa Wolford Wylam a partir de registros de conferências públicas que ocorreram no Tracing Roads Across, 2003-2006, e foi, posteriormente, elaborado pelo autor.

${ }^{2} \mathrm{NE}$ : no original em inglês: "Não se identifique com o professor e sim com o ensinamento".

Mario Biagini é ator e diretor. É o diretor associado do Workcenter of Jerzy Grotowski and Thomas Richards, do qual participa desde 1986, tornando-se rapidamente um dos membros-chave do trabalho. É responsável, desde 2007, pela direçáo, dentro do Workcenter, do Open Program, tendo dirigido, com esse time, quatro obras inspiradas na obra poética de Allen Ginsberg. É organizador da trilogia Opere e sentieri e autor de inúmeros artigos.

E-mail: info@theworkcenter.org

Traduzido do original em inglês por Elaine Padilha Guimarães. Revisão técnica de Tatiana Motta Lima e Carla Pollastrelli.

Recebido em 03 de outubro de 2012 Aprovado em 13 de dezembro de 2012 